\title{
Materyalizmin Moda Giyim İlgilenimine Etkisi Üzerine Bir Araştırma
}

\section{A Research on the Effect of Materialism on the Fashion Clothing Involvement}

\author{
Prof. Dr. Serap Çabuk - Arş. Grv. Selin Köksal Araç
}

\section{Öz}

Son yillarda moda giyime yönelik televizyon programlarının, sosyal medya paylaşımlarının ve moda ikonlarının artması üzerine bu tür konulara olan eğilimin materyalistik değerler ile ilişkisi tartışılmaya başlamıştır. Bu çalışmada materyalizmin moda giyim ürün ilgilenimine, moda giyim ürün ilgileniminin ise moda giyim satın alma ilgilenimine etkisini incelemek amaçlanmıştır. Ayrıca materyalizmin moda giyim ürün ilgilenimine etkisinde yaşın ve cinsiyet kimliğinin düzenleyici rolünü test etmek ve cinsiyete göre moda giyim ürün ilgileniminin farklılaşıp farklılaşmadı̆̆ını tespit etmek de amaçlanmaktadır. Adana İlinin en büyük alışveriş merkezinde tüketicilere anket uygulanmış ve 438 adet geçerli anket sağlanmıştır. Elde edilen veriler üzerinde faktör analizi, basit doğrusal regresyon, çoklu regresyon, hiyerarşik regresyon ve t-tesi analizleri yapilmıştır. Araştırma bulguları, materyalizmin moda giyim ürün ilgilenimini; moda giyim ürün ilgileniminin ise moda giyim satm alma ilgilenimini pozitif yönde etkilediğini göstermektedir. Moda giyim ürün ilgilenimi cinsiyete göre farklilık gösterirken; "sahip olma ve lüks düş̌ünlüğü” boyutunun moda giyim ilgilenimine etkisi yaşa ve bireyin feminenlik seviyesine bağh olarak farklilaşmaktadır.

Anahtar Kelimeler: Materyalizm, Moda Giyim İlgilenimi, Ürün İlgilenimi, Satın Alma İlgilenimi, Cinsiyet Kimliği

\begin{abstract}
Recent years, the relationship between the materialistic values and fashion clothing involvement has been started to discuss through increasing numbers of television programmes, social media shares and icons concerning fashion. In this study, it has been aimed to examine the effect of materialism on the fashion clothing product involvement and the effect of fashion clothing product involvement on the fashion clothing purchase involvement. Furthermore, it has been aimed to test the moderating effect of age and gender identity on the effect of materialism on the fashion clothing product involvement and specify whether there is a difference between gender groups for fashion clothing product involvement. The surveys were applied to consumers in one of the organized shopping malls in Adana and 438 valid questionnaire were obtained. The factor analysis, simple linear regression, multiple linear regression, hierarchical regression analysis and $t$-test were conducted for the obtained data. The findings of the study shows that materialism effects fashion clothing product involvement and fashion clothing product involvement effects fashion clothing purchase involvement positively. As, the fashion clothing product involvement differs depending on gender; the effect of possession and luxury ambition on fashion clothing product involvement differs depending on age and femininity level.
\end{abstract}

Keywords: Materialism, Fashion Clothing Involvement, Product Involvement, Purchase Involvement, Gender Identity

Prof. Dr. Serap Çabuk, Çukurova Üniversitesi İİBF, cabuks@cu.edu.tr Arş. Grv. Selin Köksal Araç, Çukurova Üniversitesi İİB, skoksal@cu.edu.tr 


\section{Giriş}

Son yıllarda dizi filmler, moda programları, özel alışveriş kulüpleri, magazin programları aracılığıyla moda giyim ilgilenimi (kişisel ilgi ve önem düzeyi) bambaşka bir boyuta bürünmüşür. Tüketicilerin moda giyim ürünlerine yönelik ilgisinin bu denli artmasında elbette ki tek sorumlu medya değildir. Peki, tüketicilerin sahip olduğu materyalistik değerlerin, içinde bulundukları yaş grubunun, cinsiyetin ve cinsiyet kimliğinin bu yönelișteki rolü nedir?

Materyalizm, Ward ve Wackman (1971, s.422) tarafından "bireylerin para ve materyalleri kişisel mutluluk ve sosyal ilerleyişleri için önemli gördükleri bir yönelim" şeklinde tanımlanmıştır. Richins ve Dawson (1992, s.307) ise materyalizm kavramını edinme (sahip olma) merkeziliği olarak değerlendirmişlerdir. Richins (1994, s.522) tüketicilerin kişisel sahipliklerinin benimsedikleri değerlerin göstergesi olduğunu öne sürmüştür. Materyalizm ile ilgili birçok çalışmada materyalist değerler ile tüketim davranışı arasındaki ilişki incelenmiştir (Fournier ve Richins, 1991; O'Cass, 2004; Handa ve Khare, 2011; Aslay vd., 2013). Materyalist değerlere sahip bireylerin tüketme eğilimlerinin de yüksek olduğu görülmektedir. Materyalizm bireylerin ürün tercihlerini belirleyen tüketim değerlerine yansımaktadır (Browne ve Kaldenberg, 1997, s.33).

Materyalizm ve tüketim ilişkisinin, sosyal imajı etkileyen görünürlüğü yüksek ürünlerde daha etkin olduğu görülmektedir (Handa ve Khare, 2011, s.113). Giyim ürünleri, sosyal görünürlügü yüksek ve materyalist değerlerle ilişkili olan başlıca ürün gruplarından birini oluşturmaktadır. Tüketicilerin moda giyim ürünlerine gösterdikleri ilgi ve önem düzeyi (ilgilenim) ve bu ürünleri satın almaya yönelik ilgilenimleri, materyalist değerlere bakış açıları ile yakından ilişkilidir (O'Cass, 2004, s.871 ; Handa ve Khare, 2011, s.113).

Tüketicilerin ürün ilgilenimi ve satın alma ilgilenimini etkileyen pazarlama kontrolünde olan ve olmayan birçok faktör bulunmaktadır. Moda giyim ürünleri ilgileniminde materyalist değerler gibi yaş ve cinsiyet demografik faktörleri de etkilidir (O'Cass, 2000, s.554; O'Cass, 2004, s.870; Handa ve Khare, 2011, s.115). O'Cass (2000, s.561) kadınların erkeklere oranla, gençlerin ise yaşlılara oranla moda giyim ilgilenimlerinin daha yüksek olduğu sonucuna ulaş- mıştır. Cinsiyet ve yaşın ötesinde, cinsiyet kimliği değişkeninin de pazarlama yazınında giyim ürünlerine yönelik çalışmalarda kullanıldığı görülmektedir. Cinsiyet kimliği, bireylerin maskülenlik ve feminenlik boyutlarına göre kendilerini nasıl tanımladıklarını ifade eder (Bem, 1981, s.356). Aiken (1963, s.125126) feminenlik ile giyim ürünlerinde uyumluluk ve giyim ürünlerine ilgi arasında pozitif ilişki olduğunu saptarken; Worth vd. (1992, s.23) tüketicilerin kotlara yönelik satın alma tercihlerinde cinsiyet kimliğinin etkili olduğunu belirlemişlerdir.

Bu çalışmada materyalizmin moda giyim ürün ilgilenimine, moda giyim ürün ilgileniminin ise moda giyim satın alma ilgilenimine etkisini incelemek ve materyalizmin moda giyim ürün ilgilenimine etkisinde yaşın ve cinsiyet kimliğinin düzenleyici rolü olup olmadığını belirlemek amaçlanmaktadır. Ayrıca, moda giyim ürün ilgileniminin cinsiyet grupları açısından farklılaşıp farklılaşmadığı da incelenecektir.

\section{Literatür Özeti \\ Materyalizm}

Materyalizm, pazarlama literatürü açısından yeni bir kavram olmamakla birlikte; dünya kaynaklarının hızla tükenmesi bu kavramı her geçen gün daha önemli bir hale getirmektedir. Tanımı konusunda tam anlamıyla bir fikir birliği sağlanmamış olan kavram bazı araştırmacılar tarafından bir kişilik özelliği olarak tanımlanırken (Parker vd., 2010, s.2); bazı araştırmacılar tarafından bir değer olarak tanımlanmaktadır (Richins ve Dawson, 1992, s.303). Materyalizm bireylerin mal edinmeye yönelik ilgisi ve maddi varlıklara bağlllık düzeyini ifade etmektedir (Belk, 1984, s.291). Sahip olma (edinme) merkeziliği olarak da ifade edilen materyalizm; mutlu olmak ve başarılı hissetmek için (ürünlere) sahip olmak anlamına gelir (Handa ve Khare, 2011, s. 38).

Belk (1985) geliştirmiş olduğu materyalizm ölçeğinde, materyalizm kavramını; sahiplik, kıskançlık ve cimrilik olmak üzere üç boyutlu bir kişilik özelliği olarak açıklamıştır (Belk, 1985, s.267-268; Khare, 2014, s. 33). Richins ve Dawson (1992, s.304) ise materyalizmi; sahip olma odaklı materyalizm (merkezilik), başarı göstergesi olarak materyalizm (başarı), mutluluğa erişmek odaklı materyalizm (mutluluk) olmak üzere üç boyutlu bir değer olarak tanımlamış- 
lardır. Başarı odaklı materyalizm, maddi varlıkların hayat başarısı ve arzu edilen imajın bir göstergesi olarak kullanılmasıdır; sahip olma odaklı materyalizm, maddi varlıkların ve bunları satın almanın bireyin yaşamındaki önemini ifade eder; mutluluk odaklı materyalizm ise, maddi varlık sahipliğinin başka nedenlerden çok mutluluk için gerekli olduğuna dair algiyı ifade eder (Auken vd., 2014, s.89). Richins ve Dawson'un geliştirmiş olduğu üç boyutlu Materyalistik Değerler Ölçeği, materyalizm ile ilgili çalışmalarda sıklıkla kullanılmaktadır (Kozar ve Marcketti, 2011, s. 396).

Materyalist bireyler, dünya varlıklarına büyük önem verirler; maddi varlıklar, bu bireylerin memnuniyet veya memnuniyetsizliklerinin odak noktasıdır (Belk, 1985, s. 265), yüksek materyalist eğilimleri olan bireyler için ürün sahipliği ve tüketim mutluluğu sembolize etmektedir (Khare, 2014, s.33). Araştırmalar, materyalizmin yalnızca insanın doğasında bulunan bir özellik olmadığını; aynı zamanda toplumda daha yüksek bir statünün yansıması olarak ürünlere sahip olmanın önemli olduğunu ortaya koymaktadır (Richins ve Dawson, 1992, s.305; Handa ve Khare, 2013, s.113 ). Bireyler sosyal görünürlüğü yüksek çeşitli ürünleri kullanarak toplumdaki statüleri ile ilgili mesajlar verirler (Khare, 2014, s. 33). Bu nedenle materyalizm ve statü ilişkisinin incelendiği alanlardan birisi de sosyal görünürlüğü yüksek ürün gruplarıdır. Moda giyim ürünleri, bireylerin sosyal statülerini yansıtmak amaçlı kullandıkları görünürlüğü yüksek ürünler arasindadır.

\section{Moda Giyim İlgilenimi}

Materyalizm kavramında olduğu gibi ilgilenim kavramı da literatürde önemli ve sık kullanılan bir kavram olmasına karşın tanımı konusunda tam bir fikir birliği sağlanamamıştır (Kandemir vd., 2013, s. 58). İlgilenim kavramı pazarlama literatürüne Krugman (1965) ile girmiştir ve bu konudaki ilk araştırmalarda ilgilenimin pazarlama araçlarının bir özelliği olduğu savunulmuştur (Krugman 1965, s.355; Wright 1974, s.194). Bu bakış açısına göre ilgilenimin düşük olduğu koşullarda tüketiciler sürekli bir reklama maruz kaldıkları için de ürünü satın alabilirler, yani tüketicilerin reklamdan sonra ürün ile ilgili farkındalıkları oluşmakta; ancak duygular ve marka tercihleri ürünün denenmesi sonrasında ortaya çıkmaktadır (Kandemir vd.,2013, s. 60).
İlgilenim temelde bilgiyi işleme isteği olarak tanımlanmaktadır (Kandemir vd., 2013, s. 62). Bilgiyi işleme isteği, kişisel ilgi ve önem düzeyi olarak da ifade edilmektedir (Odabaşı ve Barış, 2011, s. 121). Mitchell (1979, s.194) ilgilenimi bireyin herhangi bir uyaran veya duruma karşı uyarılma, ilgi ve çaba düzeyini ifade eden içsel bir değişken olarak tanımlamıştır. Cohen (1983, s.326) ise kavramı herhangi bir zaman diliminde bireyin harekete geçme seviyesi olarak ifade etmiştir. Yüksek ilgilenim durumunda uyaran ile ilgili bilgileri detaylı şekilde işlemek konusunda tüketicilerin motivasyonları da daha yüksek olmaktadır. Rothschild (1979) ilgilenimi; sürekli ve durumsal olmak üzere iki farklı boyutta ele almıştır. Sürekli ilgilenim; bireyin bir ürün, marka, reklam ya da fikre duyduğu uzun süreli bağlllıktır. Durumsal ilgilenim ise uyarana karşı geçiçi bir ilgi olup, kişinin bilişsel olarak belirli bir süre uyarıcı üzerine odaklanmasıdır (Kandemir vd., 2013, s. 60). Örneğin birçok tüketicinin çamaşır makinesine yönelik sürekli ilgilenimi söz konusu değilken; çamaşır makinesine yönelik çok yüksek bir satın alma ilgilenimi söz konusu olur (Mittal, 1989, s. 148).

İlgilenim, moda giyim ile ilgili araştırmalarda da tartışılan ve yararlanılan bir kavram olmuştur (O'Cass, 2000; Handa ve Khare, 2011). Tüketicilerin moda giyim ürünlerine yönelik ilgilenimi, sosyal ve psikolojik birçok değişkenle ilişkili olduğu için pazarlama literatürü açısından önemli bir konudur. Moda, sosyal uyum dalgasının kollektif davranış kalıbı olarak tanımlanabilir (Handa ve Khare, 2011, s. 114). Moda ürünleri bireylerin sosyal imajlarına katkıda bulunarak onların sosyal uyumluluklarını da arttırmaktadır. Moda giyim ürünleri görünürlügü yüksek bir ürün grubu olarak sosyal imaj açısından en önemli ürün grupları arasındadır. İlgilenim kavramının moda giyim açısından önemli olması da moda giyimin toplumdaki bu rolünden kaynaklanmaktadır (O'Cass; 2000, s. 547).

O’Cass (2000, s.560) moda giyim ilgilenimini; ürün ilgilenimi, reklam ilgilenimi, tüketim ilgilenimi ve satın alma kararı ilgilenimi olmak üzere 4 boyutta ele almıştır. İlgilenime yönelik kavramların farklılaşması, ilgilenim ölçeklerinin de farklı bakış açılarıyla geliştirilmesini sağlamıştır. Ölçekler genellikle kişisel önem ve ilgi düzeyi tanımına odaklanırken; bir kısmı durumsal veya sürekli ilgilenim üzerine odaklanmış- 
tır (Kandemir vd., 2013, s. 63). Laurent ve Kapferer'in geliştirmiş olduğu (1985) Tüketici İlgilenim Profili Ölçeği'ne göre tüketici ilgilenimi; algılanan risk, hata olasılı̆̆ı, sembolik değer, hedonik değer, ilgi boyutlarından oluşmaktadır. Mitttal'in (1989) geliştirmiş olduğu Satın Alma Kararı İlgilenimi Ölçeği ise tek boyutlu olup tüketicinin satın alma kararı verirken gösterdiği ilgi ve önem düzeyini belirlemeye yöneliktir. Tüketici İlgilenim Profili Ölçeği, belirli bir ürün grubuna yönelik sürekli ilgilenimi ölçmeyi amaçlarken; Satın Alma Kararı İlgilenimi Ölçeği, yalnızca belirli bir satın alma durumundaki (durumsal) ilgilenimi ölçmek amaçlı geliştirilmiştir. O’Cass (2000) tarafından geliştirilen Moda Giyim İlgilenimi Ölçeğinde de ürün ilgilenimi, tüketim ilgilenimi ve reklam ilgilenimi sürekli ilgilenimi ölçerken, satın alma kararı ilgilenimi satın alma durumunda tüketicinin ilgi ve önem düzeyini ölçmeyi amaçlamaktadır. O’Cass materyalizm ile moda giyim ilgilenimi ilişkisini incelediği başka bir çalışmasında moda giyimi yalnızca ürün ilgilenimi boyutu ile ele almıştır (O’Cass, 2004, s. 875). Moda giyim ilgilenimi ile ilgili bazı çalışmalarda ise; moda giyim ilgilenimi, ürün ilgilenimi ve satın alma ilgilenimi boyutları ile ele alınmıștır (O'Cass ve Choy, 2008; Handa ve Khare, 2011). Moda giyim ilgilenimi, tüketici davranışları ile ilgili birçok değişkende olduğu gibi psikolojik ve demografik faktörler ile ilişkilidir. Moda giyim ilgilenimi yaş ve cinsiyet demografik faktörlerinden önemli ölçüde etkilenmektedir (O’Cass, 2004, s. 869). Bu çalışmada, cinsiyet ve yaş demografik özelliklerinin yanı sıra bir psikolojik faktör olarak cinsiyet kimliğinin etkisi de incelenecektir.

\section{Cinsiyet Kimliği}

Cinsiyet biyolojik olarak farklı özellikler gösteren kadın ve erkek gruplarını ifade ederken, cinsiyet kimliğinin temelinde psikolojik ve sosyal özelliklerin farklılığı vardır (Deaux, 1985, s. 51). Cinsiyet kimliği; bireyin varoluşsal maskülenliğini veya feminenliğini ifade eder (Palan, 2001, s.1). Kavrama ilişkin yazında; "cinsiyet kimliği" yerine cinsiyet rolü veya cinsiyet kimliği rolü kavramları da kullanılabilmektedir (Stern, 1988, s. 85). 1970'lere kadar maskülenlik ve feminenlik birbirine zit kutuplar gibi görünmüş ve bireylerin bu iki kutuptan birinde yer alması gerektiği düşünülerek cinsiyet ile ilgili çalışmalarda biyolojik cinsiyet dikkate alınmıştır. 1960'lardan itibaren ise biyolojik cinsiyetin kalıplaşmış özellikleri sorgulanmaya başlamış; maskülenlik ve feminenlik boyutlarına ait özellikleri bireylerin bir arada taşımasının mümkün olduğu kabul edilmiş ve bu iki boyutlu yapı dikkate alınarak ölçekler geliştirilmiştir (Bem, 1974, s.155; Barak ve Stern, 1986, s.204; Stern, 1988, s. 86; Dökmen, 1999, s.28). Stern (1988) tüketici davranışları alanında sıklıkla başvurulan 3 cinsiyet kimliği ölçeğini kullanım yıllarına göre gruplandırmıştır (Stern, 1988, s.91):

- 1963-1971: California Psikolojik Envanteri-Feminenlik Ölçeği (CPI-Fe),

• 1976-1978: Kişisel Özellikler Anketi (PAQ),

- 1979'dan itibaren Bem Cinsiyet Rolü Envanteri (BSRI)

Bem Cinsiyet Rolü Envanteri ve Kişisel Özellikler Anketi maskülenlik ve feminenliği iki boyutlu bir yapı olarak ele almaktadır ve her iki ölçeğin Maskülenlik (M) ve Feminenlik (F) boyutları benzer ifadeler içermektedir. Bem Cinsiyet Rolü Envanteri, daha önceki ölçeklerden farklı olarak her biri 20 ifade içeren Maskülenlik ve Feminenlik Ölçekleri’nin yanısıra Sosyal Beğenirlik Ölçeği ifadelerini de içermektedir. Feminenlik Ölçeği toplumda kadınlara özgü olduğu kabul edilen özellikleri, Maskülenlik Ölçeği erkeklere özgü olduğu kabul edilen özellikleri, Sosyal Beğenirlik Ölçeği her iki cinsiyet için de kabul edilebilecek nötr özellikleri içermektedir (Bem, 1974, s.155-156). Sosyal Beğenirlik Ölçeğiini oluşturan özellikler bireylerin cinsiyet kimliğinin belirlenmesinde dikkate alınmamakta ve dolgu malzemeleri olarak görülmektedir, bu nedenle son dönemlerdeki çalışmalarda bu ölçek genellikle kullanılmamaktadır (Dökmen, 1999, s.28). Bem tarafından daha sonra ölçeğin 10 feminen ve 10 maskülen özellik içeren 20 maddelik kısa formu da geliştirilmiştir (Palan, 2001, s.10). Bem, Cinsiyet Rolü Envanteri ifadelerine göre kendisini değerlendiren bireyleri 4 gruba ayırarak incelemiştir (Stern, 1988, s.88; Hogg ve Garrow, 2003, s.166; Özkan ve Lajunen, 2005, s.103):

- Feminen (Yüksek feminenlik, Düşük maskülenlik)

- Maskülen (Yüksek maskülenlik, Düşük feminenlik)

- Androjen (Yüksek feminenlik, Yüksek maskülenlik)

- Kayıtsız (Düşük Feminenlik, Düşük Maskülenlik) 
Cinsiyet kimliği psikografik bir özellik olarak pazarlama çalışmalarında da kullanılmaktadır. Palan (2001), 1963-2001 yılları arasında cinsiyet kimliği ile ilgili yapılmış 31 tüketici davranışı araştırmasını meta analizi ile incelemiş ve araştırmaların bir kısmında cinsiyet kimliği ile tüketicilerin tutum ve davranışları arasında anlamlı bir ilişki olduğu doğrulanırken; bir kısmında biyolojik cinsiyetin tüketici davranışlarını açılamada daha etkin olduğu görülmüștür. Jaffe ve Berger'e (1988, s.259) göre ürünlerin cinsiyet kimliği, tüketicilerin cinsiyet kimliği ile ilişkili olarak satın alma tercihlerini etkiler; ancak bu ilişki ürün kategorisine bağlı olarak değişir. Worth vd.ye (1992, s.22-26) göre tüketicilerin bira ve kot tercihlerinde ürünün cinsiyet kimliği ile tüketicinin cinsiyet kimliğinin uyumlu olduğu görülmüştür.
Feiereisen vd. (2009), kadınların cinsiyet kimlikleri ile reklamlara yönelik tutumları arasındaki ilişkiyi incelenmiștir. Çabuk ve Köksal Araç (2013), cinsiyet kimliği ile ilgili tüketici araştırmalarını; reklam ile ilgili araştırmalar, ürün ve marka ile ilgili araştırmalar ve satın alma davranışı ile ilgili araştırmalar olmak üzere 3 grup altında incelemişlerdir. Bu çalışmada ise cinsiyet kimliği moda giyim ürün ilgilenimi aç1sından ele alınmıştır.

\section{Yöntem}

$\mathrm{Bu}$ çalışmada anakütleyi Adana İli’ndeki tüketiciler oluşturmaktadır. Ancak, tüketicilerin tamamına ulaşma olanağının kısıtlı olması nedeniyle çalışma evreni içerisinden bir örnek seçme yoluna gidilmiştir.
Tablo 1. Katılımcılara Ilişkin Betimleyici İstatistikler

\begin{tabular}{|c|c|c|c|}
\hline Demografik Özellikler & & Frekans & Yüzde \\
\hline \multirow[t]{2}{*}{ Cinsiyet } & Kadın & 245 & 55.9 \\
\hline & Erkek & 193 & 44.1 \\
\hline \multirow[t]{5}{*}{ Yaş } & $18-24$ yaş & 139 & 31.7 \\
\hline & $25-34$ yaş & 122 & 27.9 \\
\hline & $35-44$ yaş & 81 & 18.5 \\
\hline & $45-54$ yaş & 61 & 13.9 \\
\hline & 55 yaş ve üstü & 35 & 8.0 \\
\hline \multirow[t]{6}{*}{ Eğitim } & İlkokul & 17 & 3.9 \\
\hline & Ortaokul & 32 & 7.3 \\
\hline & Lise & 207 & 47.3 \\
\hline & Önlisans & 41 & 9.4 \\
\hline & Lisans & 107 & 24.4 \\
\hline & Lisansüstü & 34 & 7.8 \\
\hline \multirow[t]{9}{*}{ Gelir } & 1000 TL'den az & 50 & 11.4 \\
\hline & $1000-1500 \mathrm{TL}$ & 77 & 17.6 \\
\hline & $1501-2000 \mathrm{TL}$ & 73 & 16.7 \\
\hline & $2001-2500 \mathrm{TL}$ & 59 & 13.5 \\
\hline & $2501-3000 \mathrm{TL}$ & 70 & 16.0 \\
\hline & 3001-3500TL & 35 & 8.0 \\
\hline & $3501-4000 \mathrm{TL}$ & 16 & 3.7 \\
\hline & 4001-5000 TL & 28 & 6.4 \\
\hline & 5000 TL'den fazla & 30 & 6.8 \\
\hline
\end{tabular}


Adana İl merkezinde faaliyet gösteren ve geniş tüketici yelpazesine sahip olan organize alışveriş merkezlerinden alışveriş yapan tüketiciler çalışma evrenini oluşturmaktadır. Adana İl Merkezi'nde bulunan 3 organize alışveriş merkezi çalışma kapsamına alınmış, ancak bu alışveriş merkezlerinden yalnızca M1 Tepe Real Alışveriş Merkezi’nden bu çalışma için izin alınabilmiştir. Dolayısıyla çalışmanın örneklem çerçevesini Adana M1 Tepe Real Alışveriş Merkezi'nden alışveriş yapan tüketiciler oluşturmaktadır. Anketler müşteri ziyaretlerinin en fazla gerçekleştiği hafta sonu ve hafta içi bir gün (Çarşamba) seçilerek uygulanmıştır. Araştırmada anakütlenin standart sapması bilinmediği için örnek hacminin oranlar üzerinden yapılmasına karar verilmiş ve kabul edilebilir örneklem büyüklügü en az 384 olarak hesaplanmıştır (Şahin ve Atılgan, 2011, s.168; Altunışık vd., 2007, s.127). Toplamda 480 adet anket cevaplanmış, 42 hatalı anket elendikten sonra 438 adet geçerli anket sağlanmıştır. Araştırmaya katılan tüketicilerin betimleyici özellikleri Tablo 1'de verilmiştir:

Konu ile ilgili yazın taramaları ve temel araştırma sorusu çerçevesinde geliştirilen araştırma modeli Şekil 1' de yer almaktadır.

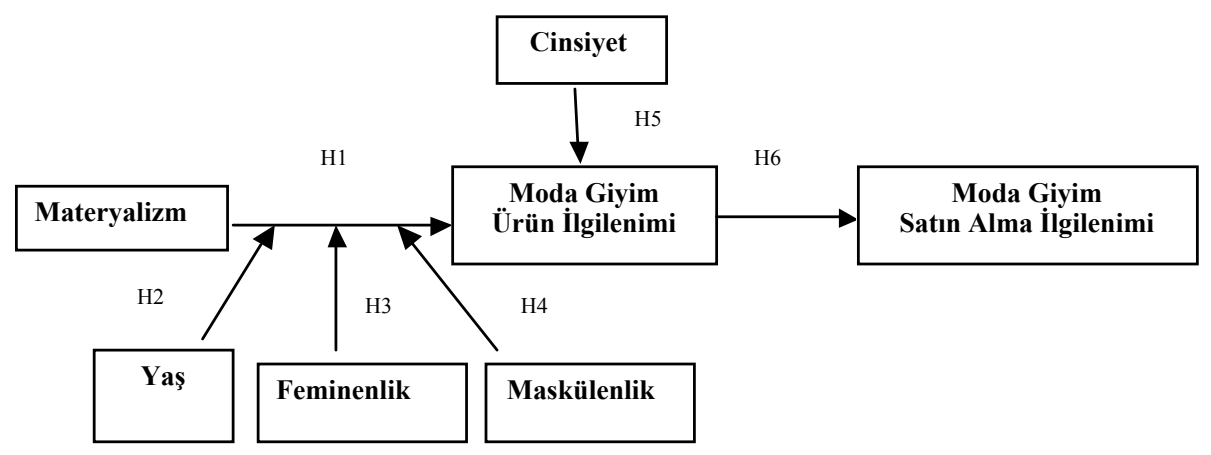

Şekil 1. Araştırma Modeli

Araştırmada materyalizmin, moda giyim ürün ilgilenimine, moda giyim ürün ilgileniminin ise moda giyim satın alma ilgilenimine etkisini incelemek amaçlanmaktadır. Ayrıca materyalizmin moda giyim ürün ilgilenimine etkisinde yaşın ve cinsiyet kimliğinin düzenleyici rolünü incelemek ve moda giyim ürün ilgileniminin cinsiyete göre farklılık gösterip göstermediğini tespit etmek de amaçlanmıştır. Bu çalışmada cinsiyet kimliği, maskülenlik ve feminenlik boyutlarıyla iki ayrı sürekli değişken olarak ele alınmışırır. Konuya ilişkin yazın taraması ve araştırma amaçları doğrultusunda aşağıdaki hipotezler geliştirilmiştir:

H1: Materyalizm, moda giyim ürün ilgilenimini pozitif yönde etkilemektedir.

H2: Materyalizmin moda giyim ürün ilgilenimi üzerindeki etkisinde yaşın düzenleyici rolü vardır.
H3: Materyalizmin moda giyim ürün ilgilenimine etkisinde bireyin feminenlik seviyesinin düzenleyici rolü vardır.

H4 Materyalizmin moda giyim ürün ilgilenimine etkisinde bireyin maskülenlik seviyesinin düzenleyici rolü vardır.

H5: Cinsiyet grupları moda giyim ürün ilgilenimi açısından anlamlı farklılık göstermektedir.

H6: Moda giyim ürün ilgilenimi, moda giyim satın alma ilgilenimini pozitif yönde etkilemektedir.

Araştırmada veri toplama yöntemi olarak anket kullanılmıştır. Ankette, Richins ve Dawson (1992) tarafından geliştirilen Materyalistik Değerler Ölçeği; O'Cass (2000) tarafından geliştirilen Moda Giyim Ürün İlgilenimi Ölçeği ve Moda Giyim Satın Alma 
Ölçeği; Bem (1974) tarafından geliştirilen Bem Cinsiyet Rolü Envanteri'nin Türkçe formu (Dökmen, 1999) ve son olarak yaş ve cinsiyet değişkenlerini belirlemeye yönelik demografik sorular yer almaktadır. Bem Cinsiyet Rolü Envanteri'nin 10 feminen 10 maskülen özellik içeren 20 maddelik kısa formu kullanılmıştır. Feminenlik Ölçeği; anlayışlı, başkalarının ihtiyaçlarına duyarlı, çocukları seven, hassas, incinmiş duyguları tamir etmeye istekli, merhametli, nazik, sempatik, sevgisini gösteren ve sıcak ifadelerinden oluşmaktadır. Maskülenlik Ölçeği ise bağımsız, baskın-tesirli, görüşünü söylemekten çekinmeyen, güçlü kişiliği olan, güçlü-kuvvetli, kendi inançlarını savunan, kendine güvenen-iddiall, liderlik yeteneklerine sahip, risk almaktan çekinmeyen ve saldırgan ifadelerinden oluşmaktadır. Materyalistik Değerler Ölçeği, Moda Giyim Ürün İlgilenimi ve Moda Giyim Satın Alma İlgilenimi Ölçeği için 5'li Likert derecelemesi (1: Hiç Katılmıyorum; 5 Tamamen Katılıyorum); Bem Cinsiyet Rolü Envanteri ifadeleri için (1: Hiç uygun değil, 5: Tamemen uygun) 5 noktalı dereceleme kullanılmıştır.

Anket formunun oluşturulmasının ardından ifadelerin anlaşılması ile ilgili bir sorun olup olmadığı belirlemek ve ölçeklerin güvenirliğini test etmek amacıyla 32 tüketici ile pilot uygulama yapılmıştır. Pilot uygulamanın ardından güvenirlik analizi yapılmış, ölçeklerin sahip olduğu Cronbach Alpha değerleri (Moda Giyim Ürün İlgilenimi; $\alpha=0.976$, Moda Giyim Satın Alma İlgilenimi $\alpha=0.943$; Materyalistik Değerler Ölçeği $\alpha=0.870$, Bem Feminenlik Ölçeği $\alpha=0.793$; Bem Maskülenlik Ölçeği $\alpha=0.796)$ ) ölçeklerin güvenirliğinin yüksek olduğunu göstermiştir. Güvenirlik analizinin ardından anket soruları ile ilgili herhangi bir sorun olmadığı tespit edilmiş ve ana saha çalışması gerçekleştirilmiştir. Anketlerin tamamlanmasının ardından; hipotez testlerinden önce değişkenlere ilişkin histogram grafiği, çarpıklık ve basıklık değerleri incelenerek dağılımların normal ya da normale yakın olduğu tespit edilmiştir. Verilerin parametrik testler için gerekli koşulları sağladığı tespit edildikten sonra faktör analizi, regresyon ve $\mathrm{t}$-testi analizleri yapılmıştır.

\section{Araştırma Bulguları}

Araştırmada kullanılan Materyalistik Değerler Ölçeği ifadelerine Açıklayıcı Faktör Analizi uygulanmıştır. Temel olarak faktör analizi, gözlenen fazla sayıdaki değişkeni daha az sayıda faktör ile açıklamaya çalışır, bunun için de değişkenler arasındaki korelasyonlar göz önünde bulundurulur (Özgür, 2003, s. 31). Öncelikle verilerin faktör analizine uygunluğu için Barlett Küresellik Testi ve Kaiser-Meyer-Olkin (KMO) uygunluk ölçüsü kullanılmıştır. Barlett Küresellik testi sonucunda $\mathrm{P}$ değerinin 0.05 'ten küçük olması $(\mathrm{p}=0.00)$ verilerin faktör analizine uygun olduğunu göstermektedir. KMO değerinin 0.841 olması ise örneklem büyüklüğünün faktör analizine uygunluğunun çok iyi olduğunu göstermektedir (Kalaycı, 2010, s. 322).

Faktör analizi sonucunda Materyalistik Değerler Ölçeği ifadeleri 3 faktör altında toplanmıştır. Faktörler altında toplanan ifadeler ve ilgili yazın dikkate alınarak 1.faktör "maddi varlık kaygısı", 2. faktör "başarı ve takdir edilme isteği", 3. faktör "sahip olma ve lüks düşkünlüğü” olarak isimlendirilmiştir. Faktör analizi sonucu oluşan boyutlar dikkate alınarak $\mathrm{H} 1, \mathrm{H} 2$, $\mathrm{H} 3$, ve $\mathrm{H} 4$ hipotezlerinin alt hipotezleri aşağıdaki gibi belirlenmiştir.

H1: Materyalizm, moda giyim ürün ilgilenimini pozitif yönde etkilemektedir.

H1a: Maddi varlık kaygısı, moda giyim ürün ilgilenimini pozitif yönde etkilemektedir.

H1b: Başarı ve takdir edilme isteği, moda giyim ürün ilgilenimini pozitif yönde etkilemektedir.

H1c: Sahip olma ve lüks düşkünlügü, moda giyim ürün ilgilenimini pozitif yönde etkilemektedir.

$\mathrm{H}$ 2: Materyalizmin moda giyim ilgilenimine etkisinde yaşın düzenleyici rolü vardır.

H2a: Maddi varlık kaygısının moda giyim ürün ilgilenimine etkisinde yaşın düzenleyici rolü vardır.

H2b: Başarı ve takdir edilme isteğinin moda giyim ürün ilgilenimine etkisinde yaşın düzenleyici rolü vardır.

H2c: Sahip olma ve lüks düşkünlügünün moda giyim ürün ilgilenimine etkisinde yaşın düzenleyici rolü vardır.

H3: Materyalizmin moda giyim ürün ilgilenimine etkisinde bireyin feminenlik seviyesinin düzenleyici rolü vardır. 
Tablo 2. Materyalistik Değerler Ölçeği Faktör Analizi Sonuç Tablosu MATERYALİSTIKK DEG̈ERLER ÖLÇEĞİ

Açıklanan Toplam Varyans Oranı:\%56,724 KMO=0.841 Barlett Testi p değeri= 0.00

\begin{tabular}{|c|c|}
\hline MADDÍ VARLIK KAYGISI $(\alpha=0.753)$ & Faktör \\
\hline Açıklanan Varyans Oranı $=\% 19.573$ & Yükleri \\
\hline Mümkün olduğunca mal mülk kaygısından uzak olacak şekilde basit yaşamaya çalışıyorum.* & .778 \\
\hline Tanıdığım çoğu insana kıyasla maddi varlıklara daha az önem veriyorum.* & .721 \\
\hline Genellikle, sadece ihtiyacım olan şeyleri satın alırım.* & .681 \\
\hline Diğer insanların sahip olduğu maddi varlıklara çok dikkat etmem.* & .639 \\
\hline Sahip olduğum maddi varlıklar benim için çok önemli değildir.* & .600 \\
\hline Hayattan zevk almak için gerçekten ihtiyacım olan her şeye sahibim.* & .500 \\
\hline \multicolumn{2}{|l|}{ BAŞARI ve TAKDÍR EDÍLME ÍSTEĠí $(\alpha=0.792)$} \\
\hline \multicolumn{2}{|l|}{ Açıklanan Varyans Oranı: \%18.642 } \\
\hline Hayattaki en önemli başarılardan bazıları maddi varlıkların kazanımını ile ilgilidir. & .863 \\
\hline Pahalı ev, araba, kıyafetlere sahip olanları takdir ederim. & .853 \\
\hline Sahip olduğum maddi varlıklar hayatta ne kadar iyi şeyler yaptığımı anlatır. & .640 \\
\hline İnsanları etkileyen şeylere sahip olmak hoşuma gider. & .517 \\
\hline
\end{tabular}

SAHİP OLMA VE LÜKS DÜŞKÜNLÜĞÜ $(\alpha=0.781)$

Açıklanan Varyans Oranı: \%18.509

\begin{tabular}{ll}
\hline Bir şeyler satın almak bana çok zevk verir. & .792
\end{tabular}

\begin{tabular}{lc}
\hline Lüks ve konforlu bir yaşamım olması hoşuma gider. & .772
\end{tabular}

\begin{tabular}{lc}
\hline Daha çok şey almaya gücüm yetseydi, daha mutlu olabilirdim. & .753
\end{tabular}

Sahip olmadığım bazı şeylere (maddi varlıklar vs.) sahip olsaydım daha iyi bir yaşamım olabilirdi. $\quad$.543

*Ifadeler ters kodlanmıştır.

H3a: Maddi varlık kaygısının moda giyim ürün ilgilenimine etkisinde bireyin feminenlik seviyesinin düzenleyici rolü vardır.

H3b: Başarı ve takdir edilme isteğinin moda giyim ürün ilgilenimine etkisinde bireyin feminenlik seviyesinin düzenleyici rolü vardır.

H3c: Sahip olma ve lüks düşkünlüğünün moda giyim ürün ilgilenimine etkisinde bireyin feminenlik seviyesinin düzenleyici rolü vardır.
H4 Materyalizmin moda giyim ürün ilgilenimine etkisinde bireyin maskülenlik seviyesinin düzenleyici rolü vardır.

H4a: Maddi varlık kaygısının moda giyim ürün ilgilenimine etkisinde bireyin maskülenlik seviyesinin düzenleyici rolü vardır.

H4b: Başarı ve takdir edilme isteğinin moda giyim ürün ilgilenimine etkisinde bireyin maskülenlik seviyesinin düzenleyici rolü vardır. 
H4c: : Sahip olma ve lüks düşkünlügünün moda giyim ürün ilgilenimine etkisinde bireyin maskülenlik seviyesinin düzenleyici rolü vardır.

Ankette kullanılan materyalizm ölçeğine ait betimleyici istatistikler Tablo 3'de gösterilmiştir. Katılımcıların materyalistik değerler ölçeği ifadelerine verdikleri yanıtların ortalamaları incelendiğinde "sahip olma ve lüks düşkünlüğü” faktörü ifadelerine verilen yanıtların ortalamalarının diğer faktörlere kıyasla daha yük- sek olduğu görülmektedir. "Sahip olma ve lüks düşkünlügü̈" faktörünü "başarı ve takdir edilme isteği” ifadeleri takip ederken, "maddi varlık kaygısı" ile ilgili ifadelere ilişkin ortalamalar görece daha düşüktür. Dolayısıyla katılımcıların daha lüks ve konforlu bir yaşam arzuladıkları; bu arzularının daha çok başarı ve takdir edilme ihtiyacının bir yansıması olduğu; "maddi varlık kaygısı"nın ise görece daha geri planda kaldığı görülmektedir.

Tablo 3. Materyalistik Değerler ölçeğine Illişkin Tanımlayıcı Istatistikler

\begin{tabular}{lcc}
\hline Materyalistik Değerler Ölçeği & Ortalama & Standart Sapma \\
\hline Maddi varlık kaygısı & 2.52 & 0.67 \\
\hline Başarı ve takdir edilme isteği & 2.97 & 0.96 \\
\hline Sahip olma ve lüks düşkünlüğ̈̈ & 3.34 & 0.85 \\
\hline
\end{tabular}

Faktör analizi ve tanımlayıcı istatistiklerin ardından, H1 hipotezini test etmek amacıyla çoklu regresyon analizi yapılmıştır. Materyalizmin moda giyim ürün ilgilenimi üzerindeki etkisini görmek amacıyla yapılan regresyon analizine ilişkin değerler Tablo 4.te gösterilmiştir.

Tablo 4. Materyalizmin Moda Giyim Ürün IIgilenimine Etkisine Illişkin Çoklu Regresyon Analizi Tablosu

\begin{tabular}{lccc}
\hline Bağımsız değişkenler & Beta & t dĕ̆eri & p dĕ̆eri \\
\hline Maddi Varlık Kaygısı & -0.20 & -0.443 & 0.658 \\
\hline Başarı ve Takdir Edilme İsteği & & & 0.008 \\
\hline Sahip Olma ve Lüks Düşkünlüğü & 0.131 & 2.663 & 0.000 \\
\hline
\end{tabular}

Bağımlı değişken: Moda Giyim Ürün İlgilenimi $\mathrm{R}=0.482 \mathrm{R}^{2}=0.232 \mathrm{~F}$ değeri $=43,799 \mathrm{p}=0.00$

Tablo 4'te görüldüğü üzere p değerinin $0.00(<0.05)$ olması materyalizmin moda giyim ürün ilgilenimini etkilediğini göstermektedir. Ancak materyalistik değerlerin moda giyim ürün ilgilenimindeki değişimleri açıklama oranı $\left(\mathrm{R}^{2}=0.232\right)$ düşüktür. Materyalizmi oluşturan alt faktörlerin beta ve $\mathrm{p}$ değerleri incelendiğinde "sahip olma ve lüks düşkünlüğü" ( $\beta=$ $0.395, p=0.00)$ ile "başarı ve takdir edilme isteği" $(\beta=0.131, p=0.008)$ faktörlerinin moda giyim ürün ilgilenimini pozitif yönde etkilediği; ancak "maddi varlık kaygısı"nın moda giyim ürün ilgilenimi üzerinde istatistiki açıdan anlamlı bir etkisinin olmadığ görülmektedir. Dolayısıyla $\mathrm{H} 1 \mathrm{~b}$ ve $\mathrm{H} 1 \mathrm{c}$ hipotezleri desteklenmiş; ancak H1a desteklenmemiştir.
Materyalizmin moda giyim ilgilenimine etkisinde yaşın düzenleyici bir rolü olduğuna ilişkin geliştirilen H2 hipotezinin test edilmesi amacıyla hiyerarşik regresyon analizi yapılmıştır. Hiyerarşik regresyon analizi yapılmadan önce bağımsız değişken ve düzenleyici değişkenlerden bu değişkenlerin ortalama puanları çıkarılarak merkezileştirme yapılmış ve merkezileştirilmiş yeni değişkenler çarpılarak etkileşim puanı elde edilmiştir. H2a hipotezi için ilk aşamada "maddi varlık kaygısı" (bağımsız değişken) ile yaş (öne sürülen düzenleyici değişken) analize tabi tutulurken; ikinci aşamada "maddi varlık kaygısı" ile yaşın etkileşimi denkleme dahil edilmiştir. H2b ve H2c hipotez- 
lerinin test edilmesi için de benzer şekilde hiyerarşik regresyon analizi yürütülmüş olup analizlere ilişkin değerler Tablo 5’te gösterilmiştir.
H2a hipotezinin test edilmesi amaciyla yürütülen hiyerarşik regresyon analizi sonucunda "maddi varlık kaygısı" ve yaşın toplam varyansın \%11.9'unu

Tablo 5. Materyalizmin Moda Giyim İlgilenimine Etkisinde Yaşın Düzenleyici Rolüne İlişkin Hiyerarşik Regresyon Analizi Tablosu

\begin{tabular}{lllllll}
\hline Aşama & Değişkenler & \multicolumn{1}{c}{$\boldsymbol{R}^{2}$} & $\boldsymbol{B}$ & $\boldsymbol{\beta}$ & $\boldsymbol{t}$ & $\boldsymbol{F}(\boldsymbol{F}$ Değişim $)$ \\
& & $\left(\boldsymbol{R}^{2} \boldsymbol{D} \boldsymbol{c} \breve{g}.\right)$ & & & & \\
\hline Aşama 1 & Maddi Varlık Kaygıs1 & .119 & -.230 & -.157 & $-3.48^{* *}$ & $29.506^{* * * *}$ \\
& Yaş & & -.023 & -.299 & $-6.64^{* * *}$ & \\
& & & & & & \\
\hline Aşama 2 & Maddi Varlık Kaygıs1 & .123 & -.256 & -.174 & $-3.72^{* * *}$ & $20.336^{* * *}$ \\
& Yaş & $(.004)$ & -.022 & -.297 & $-6.59^{* * *}$ & $(1.877)$ \\
& Maddi Varlık*Yaş & & .007 & .064 & 1.37 &
\end{tabular}

Bağımsız Değişken: Maddi Varlık Kaygısı Bağımlı Değişken: Moda Giyim İlgilenimi Düzenleyici Değişken:

Yaş

\begin{tabular}{|c|c|c|c|c|c|c|}
\hline Aşama & Değişkenler & $\begin{array}{r}R^{2} \\
\left(R^{2} D e \breve{g}\right.\end{array}$ & $B$ & $\beta$ & $t$ & $\begin{array}{l}F \\
\text { (F Değişim) }\end{array}$ \\
\hline \multirow[t]{2}{*}{ Aşama 1} & Başarı ve Takdir Edilme & .197 & .325 & .319 & $7.41^{* * *}$ & $53.217 * * *$ \\
\hline & Yaş & & -.022 & -.289 & $-6.71 * * *$ & \\
\hline \multirow[t]{3}{*}{ Aşama 2} & Başarı ve Takdir Edilme & .203 & .330 & .323 & $7.52 * * *$ & $36.765^{* * *}$ \\
\hline & Yaş & $(.006)$ & -.021 & -.276 & $-6.35 * * *$ & $(3.299)$ \\
\hline & Başarı*Yaş & & .007 & .079 & 1.82 & \\
\hline
\end{tabular}

Bağımsız Değişken: Başarı ve Takdir Edilme İsteği Bağımlı Değişken: Moda Giyim İlgilenimi Düzenleyici Değişken: Yaş

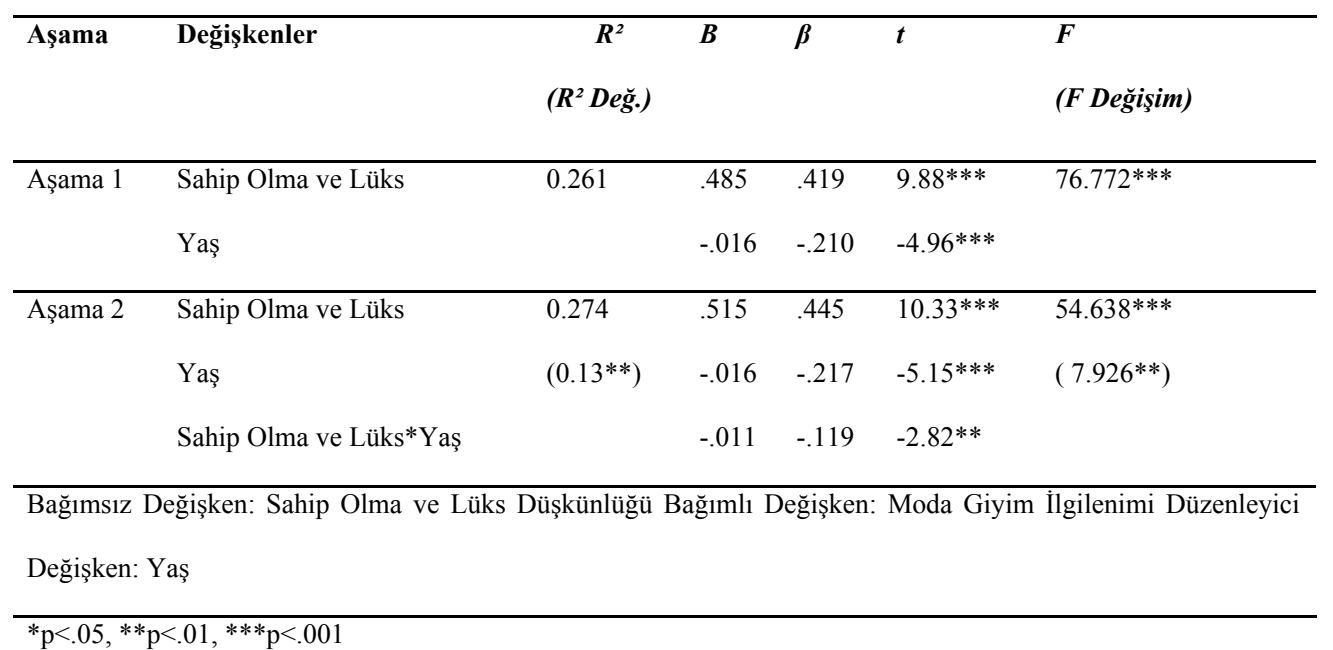


açıladığı görülmektedir. İkinci aşamada "maddi varlık kaygısı" ve yaș değişkenlerinin etkileșiminin modele eklenmesi ile toplam varyansın \%12.3'ünün açıklandığ 1 görülmektedir. Açıklanan varyans oranı artmasına karşın $\mathrm{R}^{2}$ deki değişim $\left(\Delta \mathrm{R}^{2}=.004 \mathrm{p}=.171\right)$ istatistiki açıdan anlamlı değildir. Dolayısıyla H2a hipotezi desteklenmemiştir; "maddi varlık kaygısı"nın moda giyim ürün ilgilenimine etkisinde yaşın düzenleyici bir rolü olmadığı görülmektedir. Benzer şekilde "başarı ve takdir edilme isteği”nin moda giyim ürün ilgilenimine etkisinde yaşın düzenleyici rolü olup olmadığına ilişkin $\mathrm{H} 2 b$ hipotezi için hiyerarşik regresyon analizi yapılmış; ilk aşamada varyansın \%19.7'si açıklanırken; ikinci aşamada \%20,3'ü açılanmıştır. $\mathrm{R}^{2}$ deki değişim $\left(\Delta \mathrm{R}^{2}=.006 \mathrm{p}=.070\right)$ istatistiki açıdan anlamlı değildir. H2b hipotezi desteklenmemiştir; "başarı ve takdir edilme isteği” nin moda giyim ürün ilgilenimine etkisinde yaşın düzenleyici etkisinin olmadığı görülmektedir. "Sahip olma ve lüks düşkünlügüünün moda giyim ürün ilgilenimine etkisinde yaşın düzenleyici bir rolü olup olmadığına ilişkin $\mathrm{H} 2 \mathrm{c}$ hipotezini test etmek amacıyla yapılan hiyerarşik regresyon analizi sonucunda ise $\mathrm{R}^{2}$ deki değişimin $\left(\Delta \mathrm{R}^{2}=.13 \mathrm{p}=.005\right)$ istatistiki açıdan anlamlı olduğu görülmüştür. H2c hipotezi desteklenmiştir.

"Sahip olma ve lüks düşkünlüğü” moda giyim ürün ilgilenimini etkilemekte olup; bu etki yaşa bağlı olarak değişmektedir. Bağımsız değişken ve düzenleyici değişkenin $\mathrm{R}^{2}$ değeri 0.261; tüm modelin $\mathrm{R}^{2}$ değeri ise 0.274 olup etkileşimin etki büyüklüğü hesaplanmış ve küçük etkiye $\left(f^{2}=0.018\right)$ sahip olduğu belirlenmiştir. Düzenleyici değişken olan yaşın düşük ve yüksek değerleri için regresyon katsayısının anlamlı olup olmadığının belirlenmesi için iki ayrı regresyon analizi yapılmıştır. Bu analizlerin sonuçları Tablo 6.'da gösterilmiştir.

Tablo 6. Sahip Olma ve Lüks Düşkünlüğü ile Moda Giyim Ürün IIlgilenimi Arasındaki Ilişskide Yaşın Düzenleyici Rolüne Ilişskin Tablo

\begin{tabular}{llllllll}
\hline & Bağımsız & $\boldsymbol{R}^{2}$ & $\boldsymbol{B}$ & $\boldsymbol{\beta}$ & $\boldsymbol{S E}$ & $\boldsymbol{t}$ & $\boldsymbol{F}$ \\
& Değişken & & & & & & \\
\hline Yaş & Sahip Olma ve & .274 & .373 & .322 & .063 & $5.935^{* * *}$ & $54.638^{* * *}$ \\
$($ Yüksek) & Lüks Düş. & & & & & & \\
\hline Yaş & Sahip Olma & .274 & .657 & .567 & .078 & $8.416^{* * *}$ & $54.638^{* * *}$ \\
$($ Düşük $)$ & ve Lüks Düş. & & & & & & \\
\hline${ }^{*} \mathrm{p}<.05, * * \mathrm{p}<.01, * * * \mathrm{p}<.001$ & & & & & & \\
\hline
\end{tabular}

Tablo 6’ daki değerlerden anlaşıldı̆̆ı üzere "sahip olma ve lüks düşkünlüğü”nün moda giyim ürün ilgilenimine etkisinde yaşın hem yüksek düzeyinin $(B=.373, \mathrm{t}=5.935, \mathrm{p}<0.001)$ hem de düşük düzeyinin $(B=.657, \mathrm{t}=8.416, \mathrm{p}<0.001)$ düzenleyici etkisi vardır. Yaş düştükçe "sahip olma ve lüks düşkünlügüu”nün moda giyim ilgilenimi üzerindeki etkisi artarken; yaş yükseldikçe bu etki azalmaktadır. H3 hipotezinin test edilmesi amacıyla $\mathrm{H} 2$ hipotezinde olduğu gibi hiyerarşik regresyon analizi yapılmış olup; sonuçları Tablo 7' de gösterilmiştir. "Maddi varlık kaygısı" ve "başarı ve takdir edilme isteği” değişkenlerinin moda giyim ürün ilgilenimine etkisi feminenliğe bağlı olarak farklılaşmazken; “sahip olma ve lüks düşkünlügüu”nün moda giyim ürün ilgilenimine etkisi bireyin feminenlik seviyesine göre farklılık göstermektedir.

Materyalizmin moda giyim ürün ilgilenimine etkisinde feminenliğin düzenleyici rolüne ilişkin $\mathrm{H} 3$ hipotezinin test edilmesi amacıyla yapılan hiyerarşik regresyon sonuçları "maddi varlık kaygısı" $\left(\Delta \mathrm{R}^{2}=.004\right.$ $\mathrm{p}=.182)$ ve "başarı ve takdir edilme isteği" $\left(\Delta \mathrm{R}^{2}=.005\right.$ $\mathrm{p}=.104$ ) boyutlarında feminenliğin açıklanan varyans oranını artırmasına rağmen $\mathrm{R}^{2}$ deki değişimin istatistiki açıdan anlamlı olmadığını göstermektedir. "Sahip olma ve lüks düşkünlüğü”nün, moda giyim ilgi- 
Tablo 7. Materyalizmin Moda Giyim IIlgilenimine Etkisinde Feminenliğin Düzenleyici Rolüne Illişkin Hiyerarşik Regresyon Analizi Tablosu

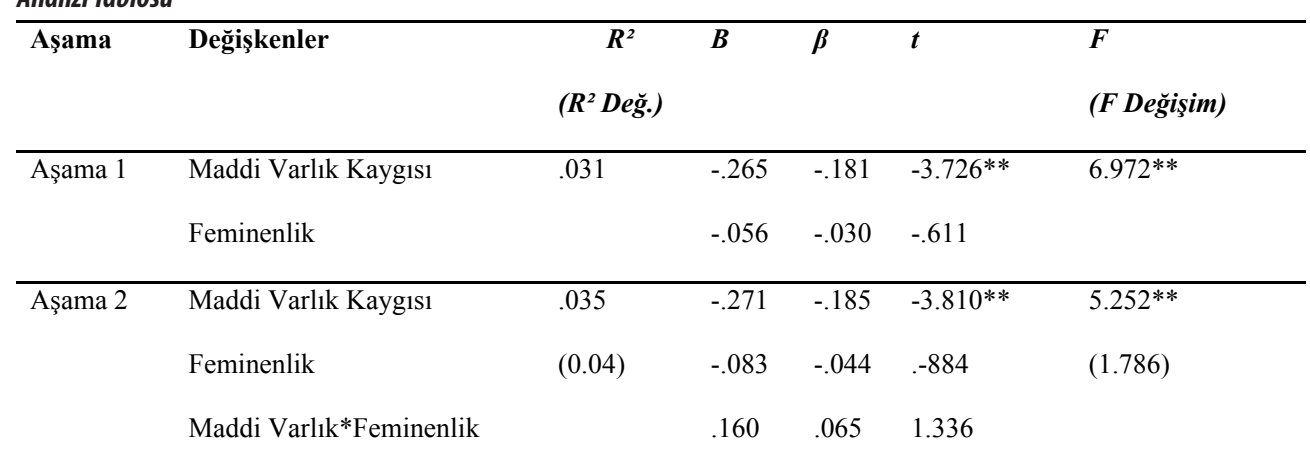

Bağımsız Değişken: Maddi Varlık Kaygısı Bağımlı Değişken: Moda Giyim İlgilenimi Düzenleyici Değişken: Feminenlik

\begin{tabular}{lllllll}
\hline Aşama & Değişkenler & $\boldsymbol{R}^{2}$ & $\boldsymbol{B}$ & $\boldsymbol{\beta}$ & $\boldsymbol{T}$ & $\boldsymbol{F}$ \\
& & $\left(\boldsymbol{R}^{2}\right.$ Dĕg.) & & & & (F Değişim) \\
\hline Aşama 1 & Başarı ve Takdir Edilme & .113 & .343 & .337 & $7.457^{* * *}$ & $27.837^{* * *}$ \\
& Feminenlik & & .022 & .012 & .263 & \\
\hline Aşama 2 & Başarı ve Takdir Edilme & .119 & .341 & .335 & $7.428^{* * *}$ & $19.513^{* * *}$ \\
& Feminenlik & $(.005)$ & .040 & .021 & .463 & $(2.653)$ \\
& Başarı*Feminenlik & & -.136 & -.074 & -1.629 &
\end{tabular}

Bağımsız Değişken: Başarı ve Takdir Edilme İsteği Bağımlı Değişken: Moda Giyim İlgilenimi Düzenleyici Değişken: Feminenlik

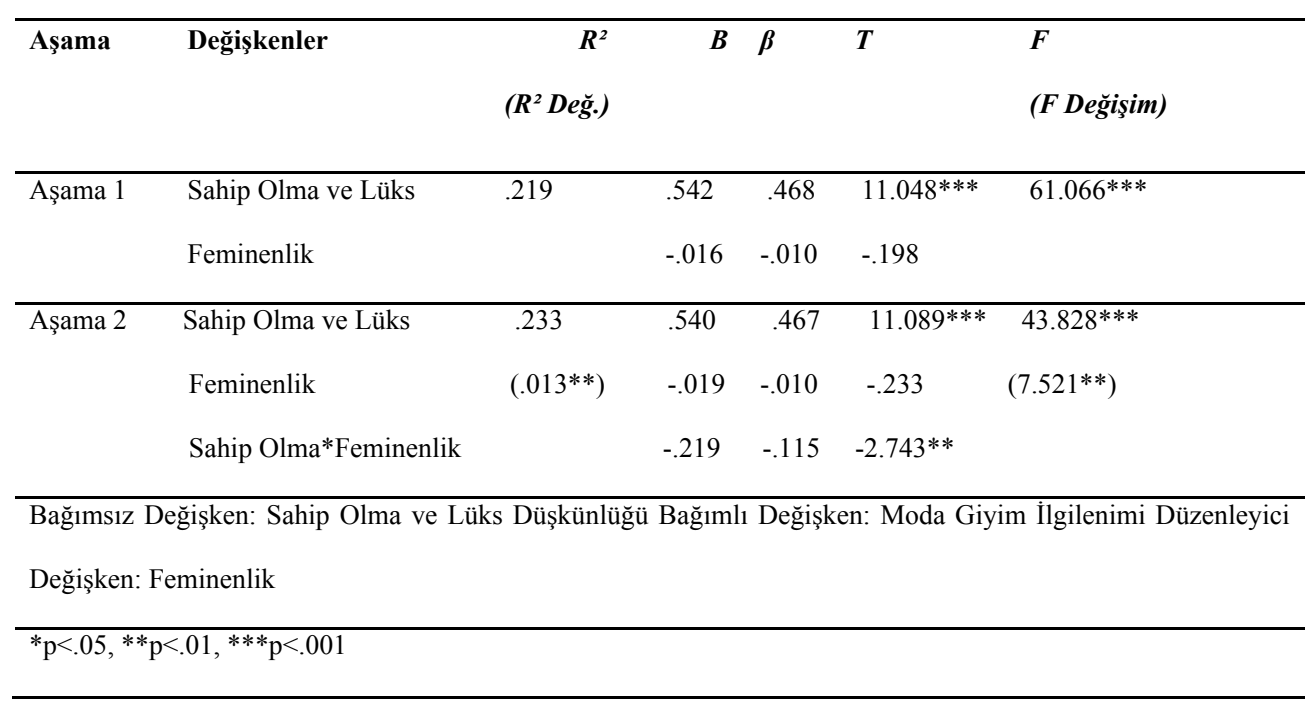


lenimine etkisinde ise bireyin feminenlik seviyesinin düzenleyici rolü olduğu tespit edilmiştir $\left(\Delta \mathrm{R}^{2}=.013\right.$ $\mathrm{p}=.006$ ). Dolayısıyla H3c hipotezi desteklenmiş olup; H3a ve H3b hipotezleri desteklenmemiștir.

“Sahip olma ve lüks düşkünlüğü” moda giyim ürün ilgilenimini etkilemekte olup; bu etki feminenlik seviyesine bağlı olarak değişmektedir. Bağımsız değiş- ken ve düzenleyici değişkenin $\mathrm{R}^{2}$ değeri 0.219 ; tüm modelin $\mathrm{R}^{2}$ değeri ise 0.233 olup etkileşimin etki büyüklüğü hesaplanmıș ve küçük etkiye $\left(f^{2}=0.018\right)$ sahip olduğu belirlenmiștir. Düzenleyici değișken olan feminenliğin düşük ve yüksek değerleri için regresyon katsayısının anlamlı olup olmadığının belirlenmesi için iki ayrı regresyon analizi yapılmıştır. $\mathrm{Bu}$ analizlerin sonuçları Tablo 8'de gösterilmiştir.

Tablo 8. Sahip Olma ve Lüks Düşkünlüğ̈̈ ile Moda Giyim Ürün IIlgilenimi Arasındaki İlişkide Feminenliğin Düzenleyici Rolüne Illişkin Tablo $\begin{array}{lllll}\text { Bağımsız Değişken } & R^{2} & B & \beta & S E\end{array}$

\begin{tabular}{|c|c|c|c|c|c|c|c|}
\hline & Bağımsız Değiş̧ken & $R^{2}$ & $\bar{B}$ & $\bar{\beta}$ & $S E$ & $t$ & $F$ \\
\hline Feminenlik & Sahip Olma ve & .233 & .426 & .368 & .064 & $6.611 * * *$ & $43.828 * * *$ \\
\hline (Yüksek) & Lüks Düş. & & & & & & \\
\hline Feminenlik & Sahip Olma & .233 & .654 & .565 & .064 & $10.292^{* * *}$ & $43.828^{* * * *}$ \\
\hline (Düşük) & ve Lüks Düş. & & & & & & \\
\hline
\end{tabular}

Tablo 8'deki değerlerden anlaşıldığı üzere "sahip olma ve lüks düşkünlüğü”nün moda giyim ürün ilgilenimine etkisinde feminenliğin hem yüksek düzeyinin $(B=.426, \mathrm{t}=6.611 \mathrm{p}<0.001)$ hem de düşük düzeyinin $(B=.654, \mathrm{t}=10.292 \mathrm{p}<0.001)$ düzenleyici etkisi vardır. Bireyin feminenlik seviyesi arttkça, "sahip olma ve lüks düşkünlüğü”nün moda giyim ilgilenimi üzerindeki etkisi azalmakta, feminenlik seviyesi azaldıkça bu etki artmaktadır.

Materyalizmin moda giyim ürün ilgilenimine etkisinde maskülenliğin düzenleyici rolüne ilişkin $\mathrm{H} 4$ hipotezinin test edilmesi amaciyla yapılan hiyerarşik regresyon sonuçları "maddi varlık kaygısı" $\left(\Delta \mathrm{R}^{2}\right.$
$=.004 \mathrm{p}=.181)$ ve "başarı ve takdir edilme isteği" $\left(\Delta \mathrm{R}^{2}\right.$ $=.002 \mathrm{p}=.358$ ) boyutlarında maskülenliğin açıklanan varyans oranını artırmasına rağmen $\mathrm{R}^{2}$ deki değișimin istatistiki açıdan anlamlı olmadığını göstermektedir; "Sahip olma ve lüks düşkünlüğü"nde ise açıklanan varyans oranı değişmemiştir; dolayısıyla $\mathrm{H} 4 \mathrm{a}$, $\mathrm{H} 4 \mathrm{~b}$ ve $\mathrm{H} 4 \mathrm{c}$ hipotezleri desteklenmemiştir.

Cinsiyet grupları arasında moda giyim ürün ilgilenimi açısından anlamlı farklılık olduğuna dair geliştirilen H5 hipotezini test etmek amacıyla bağımsız örneklem t-testi yapılmıştır. Bağımsız örneklem t-testi sonuçları Tablo 10'da gösterilmektedir: 
Tablo 9. Materyalizmin Moda Giyim IIgilenimine Etkisinde Maskülenliğin Düzenleyici Rolüne İlişkin Hiyerarşik Regresyon Analizi Tablosu

\begin{tabular}{|c|c|c|c|c|c|c|}
\hline Aşama & Değişkenler & $\begin{array}{c}R^{2} \\
\left(R^{2} \text { De ̆g. }\right)\end{array}$ & $\bar{B}$ & $\beta$ & $T$ & $\begin{array}{l}F \\
\text { (F Değişim) }\end{array}$ \\
\hline Aşama 1 & $\begin{array}{l}\text { Maddi Varlık Kaygısı } \\
\text { Maskülenlik }\end{array}$ & .050 & $\begin{array}{l}.251 \\
.304\end{array}$ & $\begin{array}{l}-.171 \\
.142\end{array}$ & $\begin{array}{l}-3.661 * * * \\
3.043 * *\end{array}$ & $11.554 * * *$ \\
\hline Aşama 2 & $\begin{array}{l}\text { Maddi Varlık Kaygısı } \\
\text { Maskülenlik } \\
\text { Maddi Varlık*Maskülenlik }\end{array}$ & $\begin{array}{l}.054 \\
(.004)\end{array}$ & $\begin{array}{l}-.248 \\
.298 \\
-.209\end{array}$ & $\begin{array}{l}-.169 \\
.140 \\
-.063\end{array}$ & $\begin{array}{l}-3.616^{* * *} \\
2.986 * * \\
-1.339\end{array}$ & $\begin{array}{l}8.314 * * * \\
(1.792)\end{array}$ \\
\hline
\end{tabular}

Bağımsız Değişken: Maddi Varlık Kaygısı Bağımlı Değişken: Moda Giyim İlgilenimi Düzenleyici Değişken: Maskülenlik

\begin{tabular}{|c|c|c|c|c|c|c|}
\hline Aşama & Değişkenler & $\begin{array}{c}R^{2} \\
\left(R^{2} D e \breve{g} .\right)\end{array}$ & $B$ & $\bar{\beta}$ & $T$ & $\begin{array}{l}F \\
(F \text { Değişim) }\end{array}$ \\
\hline \multirow[t]{2}{*}{ Aşama 1} & Başarı ve Takdir Edilme & .123 & .329 & .322 & $7.106^{* * *}$ & $30.500 * * *$ \\
\hline & Maskülenlik & & .212 & .099 & 2.189 & \\
\hline \multirow[t]{3}{*}{ Aşama 2} & Başarı ve Takdir Edilme & .125 & .321 & .315 & $6.858 * * *$ & $20.608 * * *$ \\
\hline & Maskülenlik & $(.002)$ & .204 & .095 & 2.092 & $(0.845)$ \\
\hline & Başarı*Maskülenlik & & .100 & .042 & .919 & \\
\hline
\end{tabular}

Bağımsız Değişken: Başarı ve Takdir Edilme İsteği Bağımlı Değişken: Moda Giyim İlgilenimi Düzenleyici Değişken: Maskülenlik

\begin{tabular}{|c|c|c|c|c|c|c|}
\hline Aşama & Değişkenler & $\begin{array}{c}R^{2} \\
\left(R^{2} D e \breve{g} .\right)\end{array}$ & $\bar{B}$ & $\bar{\beta}$ & $T$ & $\begin{array}{l}F \\
\text { (F Değişim) }\end{array}$ \\
\hline \multirow[t]{2}{*}{ Aşama 1} & Sahip Olma ve Lüks & .225 & .528 & .457 & $10.689^{* * *}$ & $63.073 * * *$ \\
\hline & Maskülenlik & & .163 & .076 & 1.782 & \\
\hline \multirow[t]{3}{*}{ Aşama 2} & Sahip Olma ve Lüks & 225 & .528 & .456 & $10.607 * * *$ & $41.965^{* * *}$ \\
\hline & Maskülenlik & $(0.00)$ & .163 & .076 & 1.782 & $(0.029)$ \\
\hline & Sahip Olma*Maskülenlik & & .018 & .007 & .170 & \\
\hline
\end{tabular}

Bağımsız Değişken: Sahip Olma ve Lüks Düşkünlüğü Bağımlı Değişken: Moda Giyim İlgilenimi Düzenleyici Değişken: Maskülenlik

$* \mathrm{p}<.05, * * \mathrm{p}<.01, * * * \mathrm{p}<.001$ 
Tablo 10. Cinsiyet Gruplarının Moda Giyim Ürün IIlgilenimi Açısından Farklıık Gösterip Göstermediğine ilişkin Bağımsız Örneklem t-testi Sonuç Tablosu

\begin{tabular}{lllllll}
\hline & \multicolumn{2}{c}{ Ortalama } & & Levene Testi & \multicolumn{1}{c}{ t testi } \\
\hline & Kadın & Erkek & $\boldsymbol{F}$ & $\boldsymbol{p}$ & $\boldsymbol{t}$ & $\boldsymbol{p}$ \\
& $(\mathbf{N}=\mathbf{2 4 5})$ & $(\mathrm{N}=\mathbf{1 9 3})$ & & & & \\
& & & & & & \\
\hline Ürün İlgilenimi & 3.28 & 2.43 & 23.413 & 0.00 & 10.245 & 0.00 \\
\hline
\end{tabular}

Bağımsız örneklem t-testi sonuç tablosu kadın ve erkeklerin moda giyim ürün ilgilenimi açısından farklı olduğunu $(\mathrm{p}=0.00)$ göstermektedir. H5 hipotezi desteklenmiştir. Kadınların moda giyim ürün ilgilenimi ifadelerine verdikleri yanttların ortalaması 3.28 iken; erkeklerin 2.48 'dir. Kadınların moda giyim ürün ilgilenimi erkeklerden daha yüksektir.

Moda giyim ürün ilgileniminin moda giyim satın alma ilgilenimini pozitif yönde etkilediğini öne süren H6 hipotezini test etmek amaciyla regresyon analizi yapılmış olup sonuçları Tablo 11'de gösterilmiştir.
Tablo 11'de görüldüğü üzere moda giyim ürün ilgilenimi, moda giyim satın alma ilgilenimini pozitif yönde ve güçlü bir şekilde $\left(\mathrm{R}^{2}=0.634\right)$ etkilemektedir. H6 hipotezi desteklenmiştir.

Araştırmanın temel hipotezlerine ilişkin sonuçlar Tablo 12'de özetlenmiş olup; araştırma bulguları H5 ve $\mathrm{H} 6$ hipotezlerinin desteklendiğini; $\mathrm{H} 1, \mathrm{H} 2, \mathrm{H} 3$ hipotezlerinin kısmen desteklendiğini; $\mathrm{H} 4$ hipotezinin ise desteklenmediğini göstermektedir.

Tablo 11. Moda Giyim Ürün İlgileniminin Moda Giyim Satın Alma İlgilenimine Etkisine Illşskin Regresyon Analizi Sonuç Tablosu

\begin{tabular}{lccc}
\hline Bağımsız değişkenler & Beta & t değeri & p dĕ̆eri \\
\hline Moda Giyim Ürün İlgilenimi & 0.796 & 27.476 & 0.00 \\
\hline
\end{tabular}

Bağımlı değişken: Moda Giyim Satın Alma İlgilenimi

$\mathrm{R}=0.796 \mathrm{R}^{2}=0.634 \mathrm{~F}$ değeri $=754.950 \mathrm{p}=0.00$

Tablo 12. Araştırmanın Temel Hipotezlerine iliş̧kin Özet Sonuç Tablosu

\begin{tabular}{lc}
\multicolumn{1}{c}{ Hipotez } & Sonuç \\
\hline H1: Materyalizm, moda giyim ürün ilgilenimini pozitif yönde etkilemektedir. & Kısmen Desteklenmiştir. \\
\hline $\begin{array}{l}\text { H2: Materyalizmin moda giyim ilgilenimine etkisinde yaşın düzenleyici rolü } \\
\text { vardır. }\end{array}$ & Kısmen Desteklenmiştir. \\
\hline $\begin{array}{l}\text { H3: Materyalizmin moda giyim ürün ilgilenimine etkisinde bireyin feminenlik } \\
\text { seviyesinin düzenleyici rolü vardır. }\end{array}$ & Kısmen Desteklenmiştir. \\
\hline $\begin{array}{l}\text { H4: Materyalizmin moda giyim ürün ilgilenimine etkisinde bireyin } \\
\text { maskülenlik seviyesinin düzenleyici rolü vardır. }\end{array}$ & Desteklenmemiştir. \\
\hline $\begin{array}{l}\text { H5: Cinsiyet grupları moda giyim ürün ilgilenimi açısından anlamlı farklılık } \\
\text { göstermektedir. }\end{array}$ & Desteklenmiştir. \\
\hline
\end{tabular}

H6: Moda giyim ürün ilgilenimi, moda giyim satın alma ilgilenimini pozitif yönde etkilemektedir.

Desteklenmiştir. 


\section{Sonuç}

Moda giyim ürünleri, görünürlüğü yüksek bir ürün grubu olarak materyalistik değerler ile yakından ilişkilidir. Bu çalışma ile materyalistik değerlerin moda giyim ürün ilgilenimine, moda giyim ürün ilgileniminin ise moda giyim satın alma ilgilenimine etkisini incelemek; materyalizmin moda giyim ürün ilgilenimine etkisinde yaş, feminenlik ve maskülenliğin düzenleyici rolü olup olmadığını test etmek ve cinsiyet grupları açısından moda giyim ürün ilgileniminin farklılaşıp farklılaşmadığını belirlemek amaçlanmıştır. Anket yöntemi ile 438 katılımcıdan toplanan verilerin analizinde faktör analizi, basit doğrusal regresyon, çoklu regresyon, hiyerarşik regresyon ve t-testi kullanılmıştır.

Çalışmada öncelikle Materyalistik Değerler Ölçeği ifadelerine faktör analizi uygulanmış; faktör analizi sonucu ifadeler "maddi varlık kaygısı", "başarı ve takdir edilme isteği" ve "sahip olma ve lüks düşkünlüğü" olmak üzere 3 boyut altında toplanmıştır. Araştırma bulguları,"başarı ve takdir edilme isteğì" ve "sahip olma ve lüks düşkünlügü̆” boyutlarının moda giyim ürün ilgilenimini anlamlı bir şekilde etkilediğini göstermektedir. Goldsmith vd. (2012, s.114-115) de benzer şekilde materyalizm ve statü tüketiminin giyim ilgilenimini pozitif yönde etkilediğini; bireylerin giyim ilgilenimi ve bazı giyim markalarına ilişkin bağl1lıkları aracıllı̆ ihtiyaçlarını gidermeye çalıştıklarını ortaya koymuşlardır . "Maddi varlık kaygısı" boyutunun ise moda giyim ürün ilgilenimi üzerinde anlamlı bir etkisinin olmadığı görülmektedir. "Maddi varlık kaygısı" yüksek olan bireyler için maddi tüketimler araçtan öte amaçtır (Doğan, 2010, s. 59); bu durum maddi varlık kaygısının moda giyim ilgilenimi üzerinde anlamlı bir etkisi olmayışını kısmen açıklamaktadır. Maddi varlık kaygısı yüksek olan bireyler mutluluk arayışı veya statü kaygısı peşinde olmasalar da maddi varlıklara sahip olmak isterler.

Materyalizmin moda giyim ürün ilgilenimine etkisinde yaş ve cinsiyet kimliği değişkenlerinin düzenleyici rolünü test etmek amacıyla hiyerarşik regresyon analizi yapılmıştır. Cinsiyet kimliği, maskülenlik ve feminenlik boyutlarıyla iki ayrı sürekli değişken olarak ele alınmıştır. Materyalizmin moda giyim ilgilenimine etkisinde yaşın düzenleyici rolüne ilişkin araştırma bulguları "sahip olma ve lüks düşkünlügüünün moda giyim ilgilenimine etkisinin yaşa bağlı olarak değişti- ğini; ancak "maddi varlık kaygısı" ve "başarı ve takdir edilme isteği” değişkenlerinin moda giyim ilgilenimine etkisinde yaşın düzenleyici etkisi bulunmadığını göstermektedir. Benzer şekilde bireyin feminenlik seviyesi, "sahip olma ve lüks düşkünlügüünün moda giyim ürün ilgilenimine etkisinde düzenleyici role sahiptir. Materyalistik değerlerin moda giyim ilgilenimine etkisinde bireyin maskülenlik seviyesinin ise düzenleyici rolü olmadığı görülmektedir. Moda giyim ilgileniminin cinsiyete bağlı olarak farklılaştı̆̆ı; kadınların moda giyim ürünlerine yönelik ilgilenimlerinin erkeklerden daha yüksek olduğu belirlenmiştir. Moda giyim ürün ilgileniminin, moda giyim satın alma ilgilenimi üzerindeki etkisine yönelik araştırma bulguları ise ürün ilgileniminin satın alma ilgilenimini pozitif yönde ve güçlü bir şekilde etkilediğini göstermektedir. Bu çalışmanın bulguları ile tutarlı olarak, Hourigan ve Bougoure (2012, s.132) materyalist bireylerin ve kadınların moda giyim ilgilenimlerinin daha yüksek olduğunu ortaya koymuşlardır. Handa ve Khare (2011, s.118) de çalışmalarının sonucunda genç kadınların moda giyim ürün ve satın alma ilgilenimlerinin daha yüksek olduğunu; ayrıca moda giyim ürün ilgilenimi ve moda giyim satın alma ilgilenimi arasında yüksek korelasyon bulunduğunu tespit etmişlerdir. O'Cass (2004, s.877) materyalizm, yaş ve cinsiyetin moda giyim ilgilenimini etkilediği; metaryalist bireylerin, kadınların ve gençlerin daha yüksek moda giyim ilgilenimine sahip olduğu sonucuna ulaşmıştır. Bu çalışma literatürdeki birçok araştırma ile tutarlı bulgulara ulaşmasının yanı sıra cinsiyet kimliğinin etkisini incelemesi bakımından özgünlük taşımaktadır.

Araştırma bulguları genel olarak değerlendirildiğinde, moda giyim ürün ilgileniminin "başarı ve takdir edilme isteği" ve "sahip olma ve lüks düşkünlügüu" değerlerinin yansıması olduğu; bireylerin yaşı ilerledikçe ve feminenlik seviyesi arttıkça "sahip olma ve lüks düşkünlüğü”nün moda giyim ürün ilgilenimine etkisinin azaldığı görülmektedir. Sosyal görünürlüğü yüksek bir ürün grubu olarak moda giyim ürünleri "başarı ve takdir edilme", "sahip olma ve lüks düşkünlüğü” ile ilişkili iken "maddi varlık kaygısı" daha çok, yüksek bütçeler gerektiren ve kişinin yaşam refahını etkileyen varlıklar (ev, otomobil, menkul kıymetler vb.) ile ilişkilidir, bu nedenle de moda giyim ilgilenimini etkilememektedir. Bireylerin yaşı ilerledikçe "sahip olma ve lüks düşkünlügü" değerlerine verilen önem azaldığ i için, yaşın "sahip olma ve lüks düşkün- 
lüğü” ile moda giyim ilgilenimi ilişkisinde düzenleyici rolü bulunmaktadır. Benzer şekilde feminenlik, materyalistik değerlerin aksine daha çok insani değerler ile ilişkili olduğundan (Bem, 1974, s.156) feminenlik seviyesi arttıkça "sahip olma ve lüks düşkünlügü” değerlerine verilen önem azalmaktadır.

$\mathrm{Bu}$ konuya ilişkin gelecek araştırmalarda ürün ve satın alma ilgilenimi boyutlarına ek olarak reklam ilgilenimi ve tüketim ilgilenimi boyutlarının da ele alınması, cinsiyet kimliği dışındaki diğer psikolojik faktörlerin de düzenleyici etkisinin değerlendirilmesi literatüre önemli katkılar sağlayacaktır.

Moda giyim sektöründe faaliyet gösteren işletmeler açısından yaş, cinsiyet ve cinsiyet kimliği değişkenlerinin dikkate alınması önemlidir. Özellikle hedef kitlenin yaşı arttıkça; ürün tutundurma faaliyetlerinde materyalistik değerler yerine başka değerlere vurgu yapılması gerekmektedir. Hedef kitlenin feminen özelliklere sahip olduğu belirlenmişse, benzer şekilde materyalistik öğelerin geri planda kalması ve ürün/ markanın daha çok insani değerler ile bağdaştırılması tercih edilmelidir.

\section{Kaynakça}

Aiken, L. R. (1963). The Relationships of Dress to Selected Measures of Personality in Undergraduate Women. The Journal of Social Psychology, 59 (1), 119-128.

Altunışık, R. Coşkun, R., Bayraktaroğlu S. \& Yıldırım E. (2007). Sosyal Bilimlerde Araștırma Yöntemleri (5. Baskı), Adapazarı:Sakarya.

Aslay, F., Ünal, S., Akbulut, Ö. (2013). Materyalizmin Statü Tüketimi Üzerindeki Etkisini Belirlemeye Yönelik Bir Araştırma. Atatürk Üniversitesi İktisadi ve İdari Bilimler Dergisi, 27 (2), 43-62.

Auken S. V., Wells L. G., Borgia D. J. (2014). Assessing Materialism Among the Future Elites of China. Journal of International Consumer Marketing, 26 (2), 88-105

Barak, B., Stern, B. (1986). Sex-linked Trait Indexes Among Baby-boomers and Pre-boomers: A Research Note. Advances in Consumer Research, 13 (1), 204-209.
Belk, R.W. (1984). Three Scales to Measure Constructs Related to Materialism:Reliability, Validity, and Relationships to Measures of Happiness. T. Kinnear(Ed.), Advances in Consumer Research içinde, 11, 291-297.

Belk, R. W. (1985). Materialism: Trait Aspects of Living In the Material World. Journal of Consumer Research, 12, 265-280.

Bem, S. L. (1974). The Measurement of Psychological Androgyny. Journal of Consulting and Psychology, 42 (2), 155-162.

Bem, S. L. (1981). Gender Schema Theory: A Cognitive Account of Sex Typing. Psychological Review, 88 (4), 354-364.

Browne, B., Kaldenberg, D. (1997). Conceptualzing Self-monitoring: Links to Materialism and Product Involvement. Journal of Consumer Marketing, 14 (1), 31-44.

Cohen, J. B. (1983). Involvement and You: 1,000 Great Ideas., R. P. Bagozzi \& A. M. Tybout (Ed.), Advances in Consumer Research içinde, 10, 325-328.

Çabuk, S., Araç, S. K. (2013). Psikografik Bir Pazar Bölümlendirme Değişkeni Olarak Cinsiyet Kimliği: Tüketim Araştırmalarında Cinsiyet Kimliği Kavramının İncelenmesi. Çukurova Üniversitesi Sosyal Bilimler Enstitüsü Dergisi, 22 (2), 27-40.

Deaux, K. (1985). Sex and Gender, Annual Review of Psychcology. 36, 49-81.

Dökmen, Z. Y. (1999). Bem Cinsiyet Rolü Envanteri Kadınsılık Ve Erkeksilik Ölçekleri Türkçe Formunun Psikometrik Özellikleri. Kriz Dergisi, 7 (1), 27-40.

Doğan, S. Y. (2010). Materyalist Eğilimlerin Demografik Özelliklere Göre Farklılaşmasına Yönelik Bir Araştırma, C.Ü. İktisadi ve İdari Bilimler Dergisi, 11 (1), 57-70.

Feiereisen, S., Broderick, A., Douglas, S. P. (2009). The Effect and Moderation Of Gender Identity Congruity: Utilizing "Real Women" Advertising Images. Pscychology\&Marketing, 26 (9), 813-843. 
Fournier, S., Richins, M. L. (1991). Some Theoretical and Popular Notions Concerning Materialism. Journal of Social Behavior and Personality, 6, 403-414.

Goldsmith, R. E., Flynn, R. E. \& Clark, R.A. (2012). Materialistic, Brand Engaged and Status Consuming Consumers and Clothing Behaviors. Journal of Fashion Marketing and Management, 16 (1), 102119.

Handa, M., Khare, A. (2011). Gender as a Moderator of the Relationship Between Materialism and Fashion Clothing Involvement Among Indian Youth, International Journal of Consumer Studies, 37, 112120.

Hogg, M.K., Garrow, J. (2003). Gender, Identity and the Consumption of Advertising, Qualitative Market Research, 6 (3), 160-174.

Hourigan S.R., Bougoure U.S. (2012). Towards a Better Understanding of Fashion Clothing Involvement, Australasian Marketing Journal, 20, 127-135.

Jaffe, L.Y., Berger P. D. (1988). Impact on Purchase Intent of Sex-role Identity and Product Positioning. Psychology \&Marketing, 5 (3), 259-271.

Kalaycı, Ş. (2010). SPSS Uygulamalı Çok Değişkenli İstatistik Teknikleri. Ankara:Asil.

Kandemir, D., Atakan, S., Demirci, C. (2013). İlgilenim Kavramı veTürkçe İlgilenim Ölçeklerinin Değerlendirilmesi: Tüketici İlgilenimi, Sürekli İlgilenim, Satın Alma Kararı İlgilenimi. İktisat İşletme ve Finans, 28 (331), 57-88.

Khare, A. (2014). Money Attitudes, Materialism, and Compulsiveness: Scale Development and Validation. Journal of Global Marketing, 27 (1), 30-45.

Kozar J.M., Marcketti S. B. (2011). Examining Ethics and Materialism with Purchase of Counterfeits, Social Responsbility Journal, 3 (3), 393-404.

Krugman, H. E. (1965). The Impact of Television Advertising: Learning without Involvement. Public Opinion Quarterly, 29, 349-356.
Laurent G., Kapferer, J. (1985). Measuring Consumer Involvement Profiles. Journal of Marketing Research, 22, 41-53.

Mitchell, A. A. (1979). Involvement: A potentially Important Mediator of Consumer Behavior. W. L. Wilkie (Ed.), Advances in Consumer Research içinde, 6, 191-196.

Mittal, B. (1989. Measuring Purchase Decision Involvement. Psychology and Marketing, 6 (2), 147-162.

O'Cass, A. (2000). An Assessment of Consumers' Product, Purchase Decision, Advertising and Consumption Involvement in Fashion Clothing. Journal of Economic Psychology, 21, 545-576.

O'Cass, A. (2004). Fashion Clothing Consumption: Antecedents and Consequences of Fashion Clothing Involvement. European Journal of Marketing, $38,869-882$.

O'Cass, A., Choy, E. (2008). Chinese Generation Y Consumers' Involvement in Fashion Clothing. Journal of Product \& Brand Management, 17, 341352.

Odabaşı, Y. \& Barış, G. (2002). Tüketici Davranışı (11. Baskı), İstanbul: MediaCat.

Özgür, E. (2003). Çok Değişkenli İstatistiksel Analiz Yöntemleri ve Bir Uygulama. Doktora Tezi, Gazi Üniversitesi Sosyal Bilimler Enstitüsü, Ankara.

Özkan, T., Lajunen T. (2005). Masculinity, Femininity and the Bem Sex Role Inventory in Turkey. Sex Roles, 52 (1-2), 103-110.

Palan K.M (2001). Gender Identity in Consumer Behavior Reserach: A Literature Review and Research Agenda. Academy of Marketing Science, 10, 1-24.

Parker, R. S., Haytko, D., Hermans, C. (2010). The Perception of Materialism in a Global Market: A Comparison of Younger Chinese and United States Consumers, Journal of International Business and Cultural Studies, 3, 1-13. 
Richins, M. L., Dawson, S. (1992). A Consumer Values Orientation for Materialism and Its Measurement: Scale Development and Validation. Journal of Consumer Research, 19, 303-316

Richins, M. L. (1994). Special Possessions and the Expression of Material Values. Journal of Consumer Research, 21 (December), 522-533.

Rothschild, M. L. (1979). Advertising Strategies for High and Low Involvement Situations. C. Maloney \& B. Silverman (Ed.), Attitude Research Plays for High Stakes içinde (s.74-93), Chicago, IL: American Marketing Association.

Stern, B. B. (1988). Sex-Role Self-Concept Measures and Marketing: A Research Note. Psychology\& Marketing, 5 (1), 85-99.
Şahin, A., Atılgan, K. Ö. (2011). Örnekleme Süreci ve Uygulanması, A. Şahin \& B.Kartal (Ed.) Pazarlama Araştırmast içinde (s. 149-175). İstanbul:Lisans.

Ward, S., Wackman, D. (1971). Family and Media Influences on Adolescent Consumer Learning. American Behavioral Scientist, 14, 415-427.

Worth, L.T., Smith, J., Mackie, D. M. (1992). Gender Schematicity and Preference for Gender Typed Products. Psychology\& Marketing, 9 (1),17-30.

Wright, P. L. (1974). Analyzing Media Effects on Advertising Responses. Public Opinion Quarterly, 38, 192-205. 